
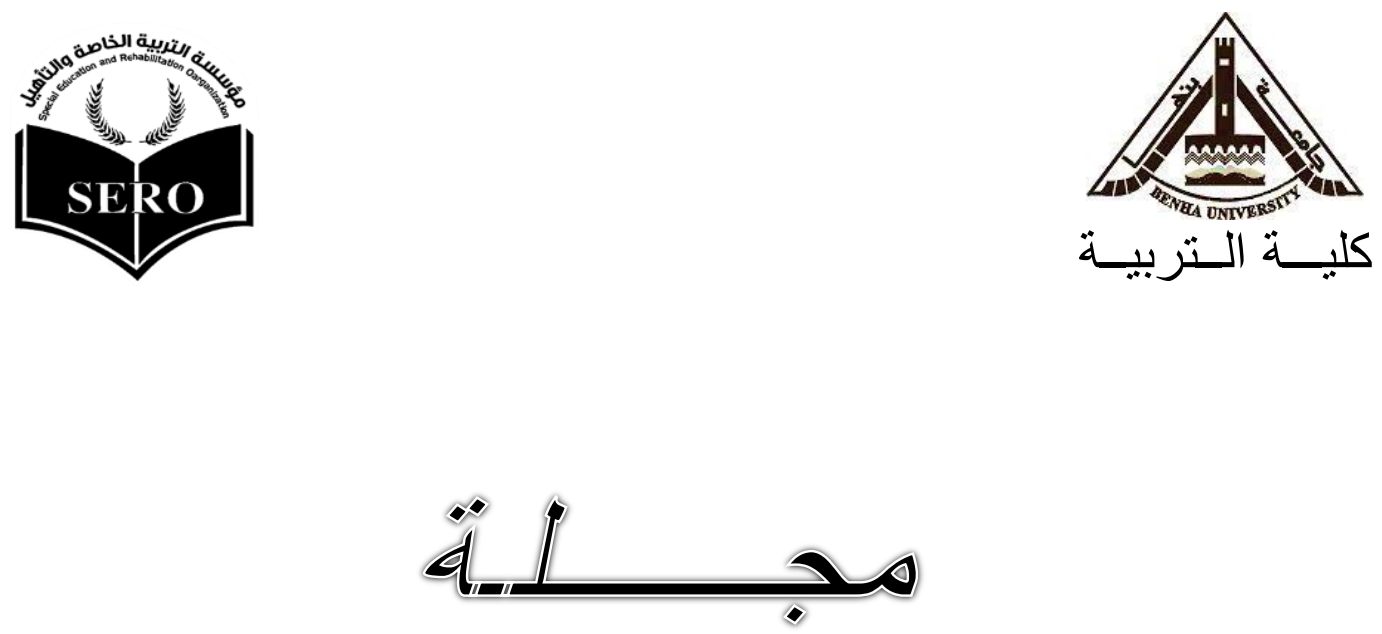

$$
\text { التربية الخـاصة و التأهيل }
$$

"إقليمية - علميــة ـ دوريـــة ـ محكمـة ـ متخصصــة"

$$
\text { تصسـلدر عـن }
$$

مؤسسة التربية الخاصية والتأهيل (SERO)

بالتعـاون العلمي مـع كلية التربية - جـامعـة بنهـا

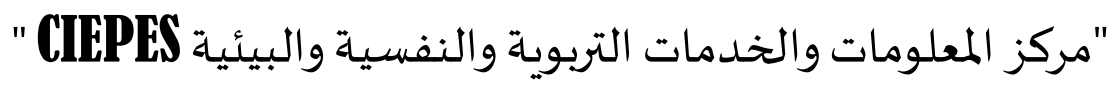

$$
\begin{aligned}
& \text { ترقيم دولي: ISSN2314-8608 }
\end{aligned}
$$

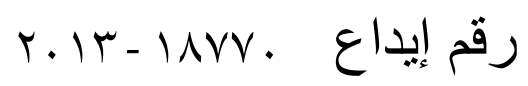

$$
\begin{aligned}
& \text { المجلد السادس - العدد الثاني و العشرون - الجزءء الأول }
\end{aligned}
$$

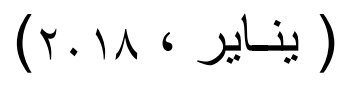




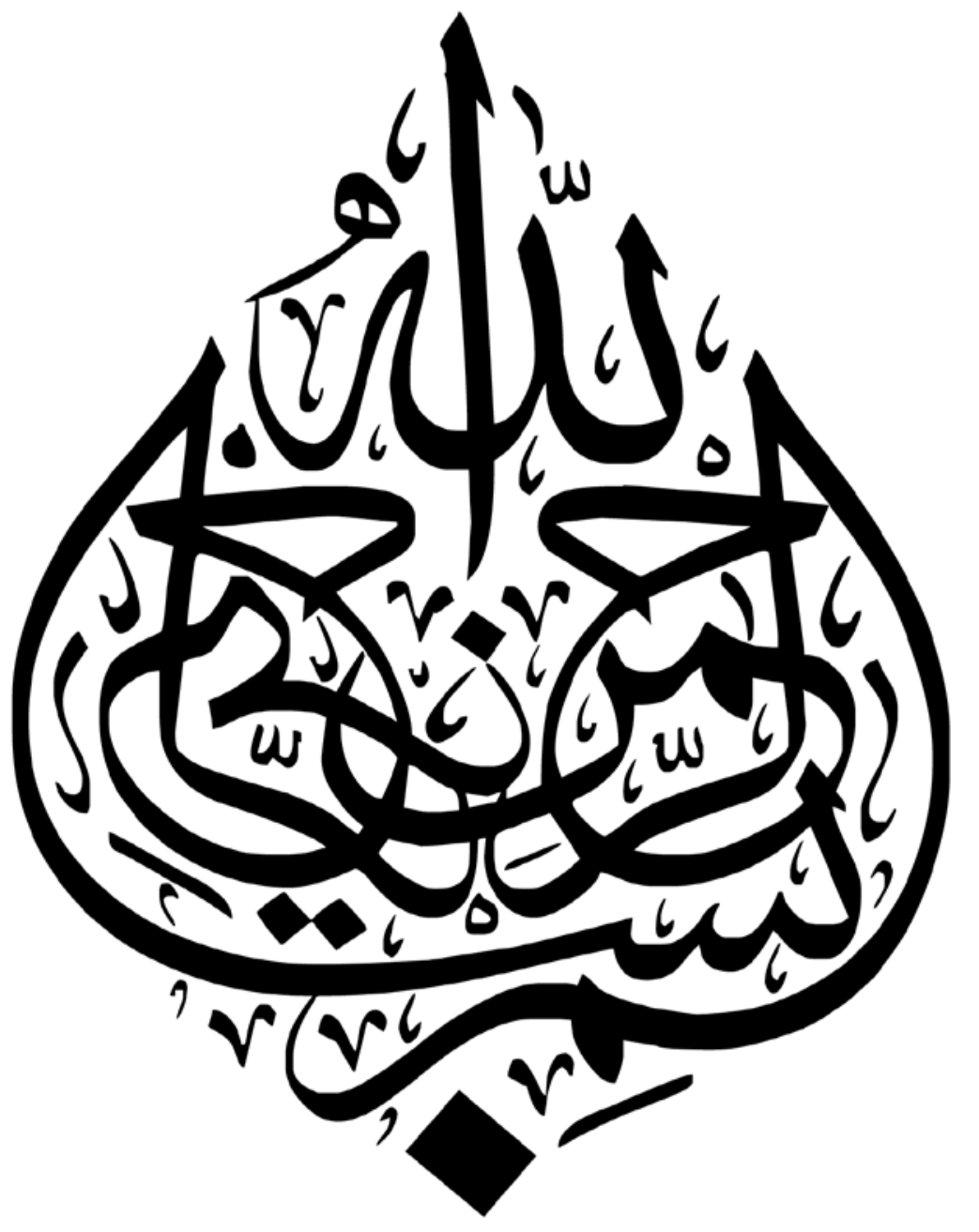




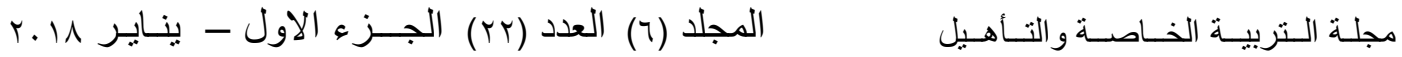

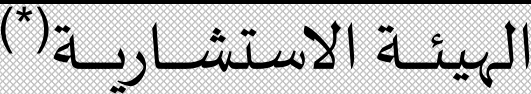

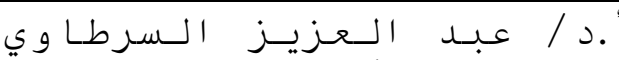

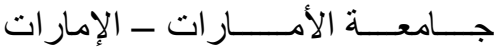

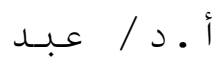

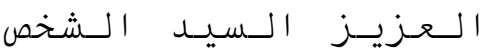

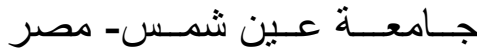

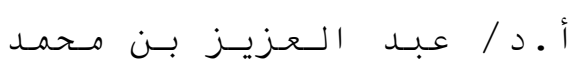

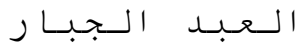

جامعة الملك سعود- السعودية

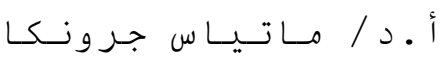

Matthias Grïnke

جامعة كولونيا_ المانيا

\section{University of Cologne-German}

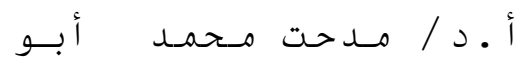

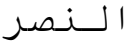

جـــــة حلــوان - مصــر

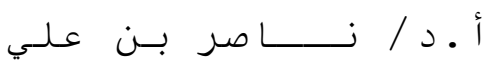

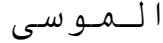

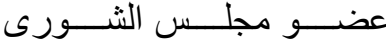

أمين عام التربية الخاصة بالسعودية سابقا

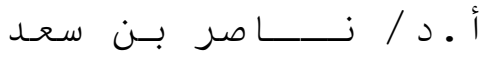

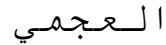

المدير التنفيذي لبرنامج الوصول الثشامل بجامعة إندية

الملك سعود ورئيس مجلس إدارة الجمعية السعودية المئية اللتربية الخاصة

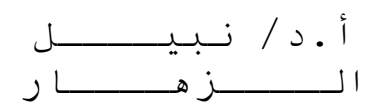

عميد كلية التربية الخاصة جامعة مصر للعلوم والتكنولوجيا

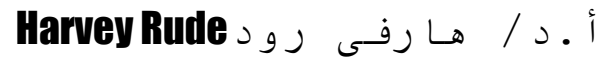

جامعة شمال كولور ادو - الولايات المتحدة الامريكية University of Northern Colorado-USA

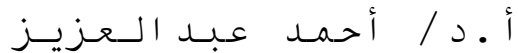

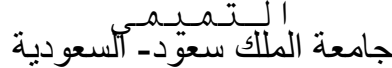

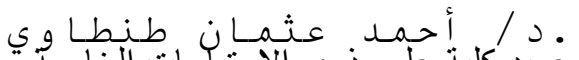

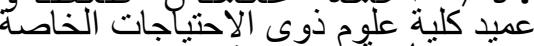

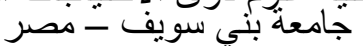

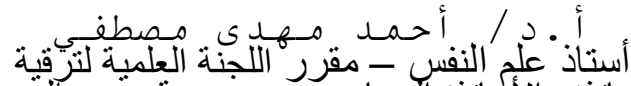

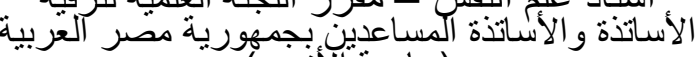
(جامعة الآز هر)

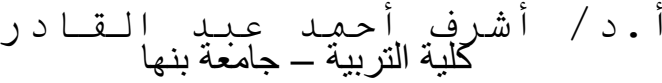

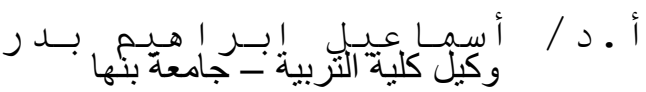

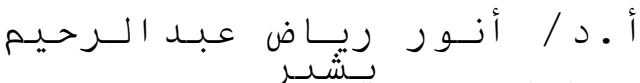

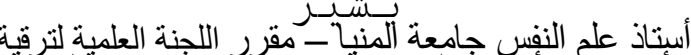

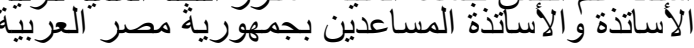

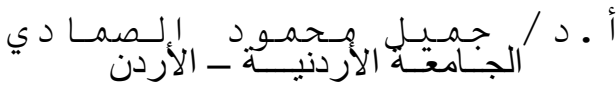

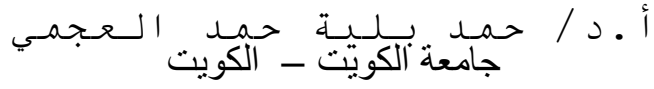

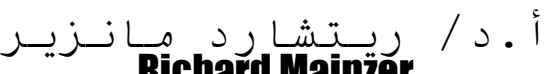

مستشار مجلس الاطففال غير الُعاديين الامريكى (CEC)

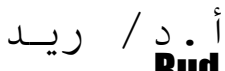 \\ Rud Turnbull

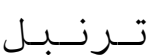

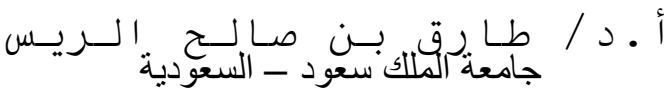

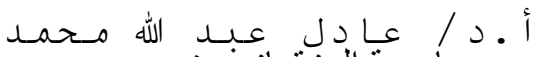

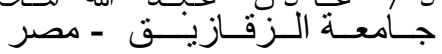




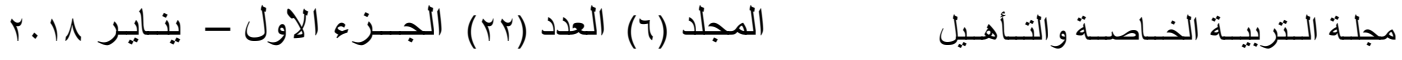

\section{هيئنة التحصربر}

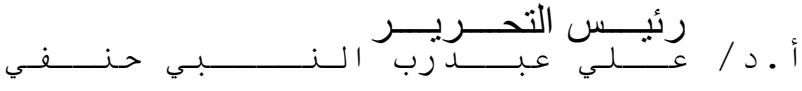

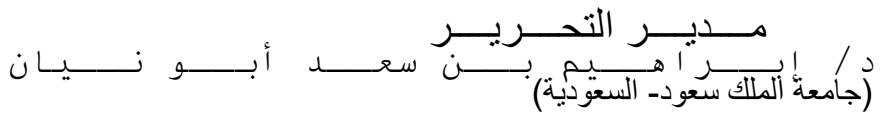

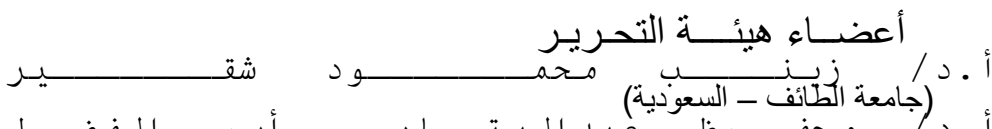

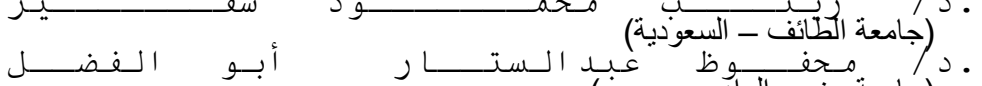

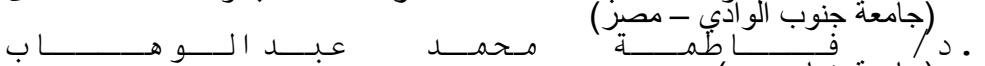

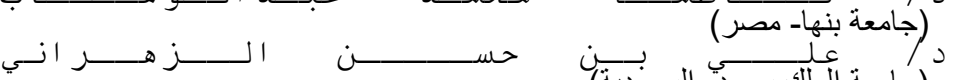

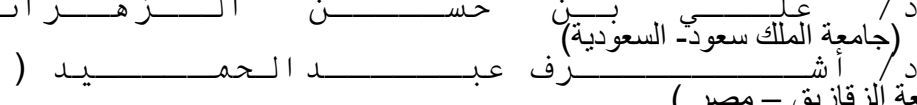

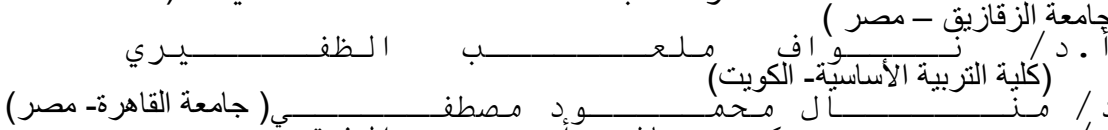

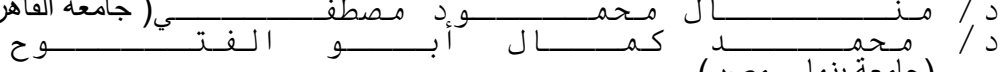

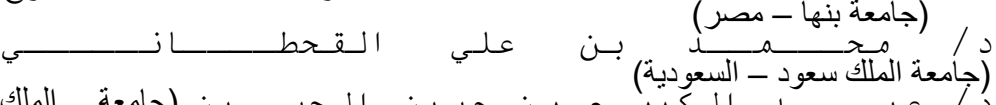

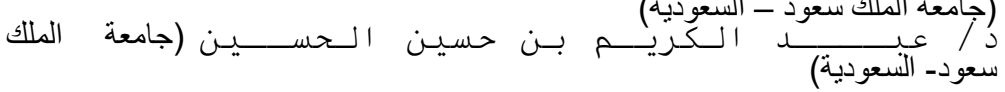
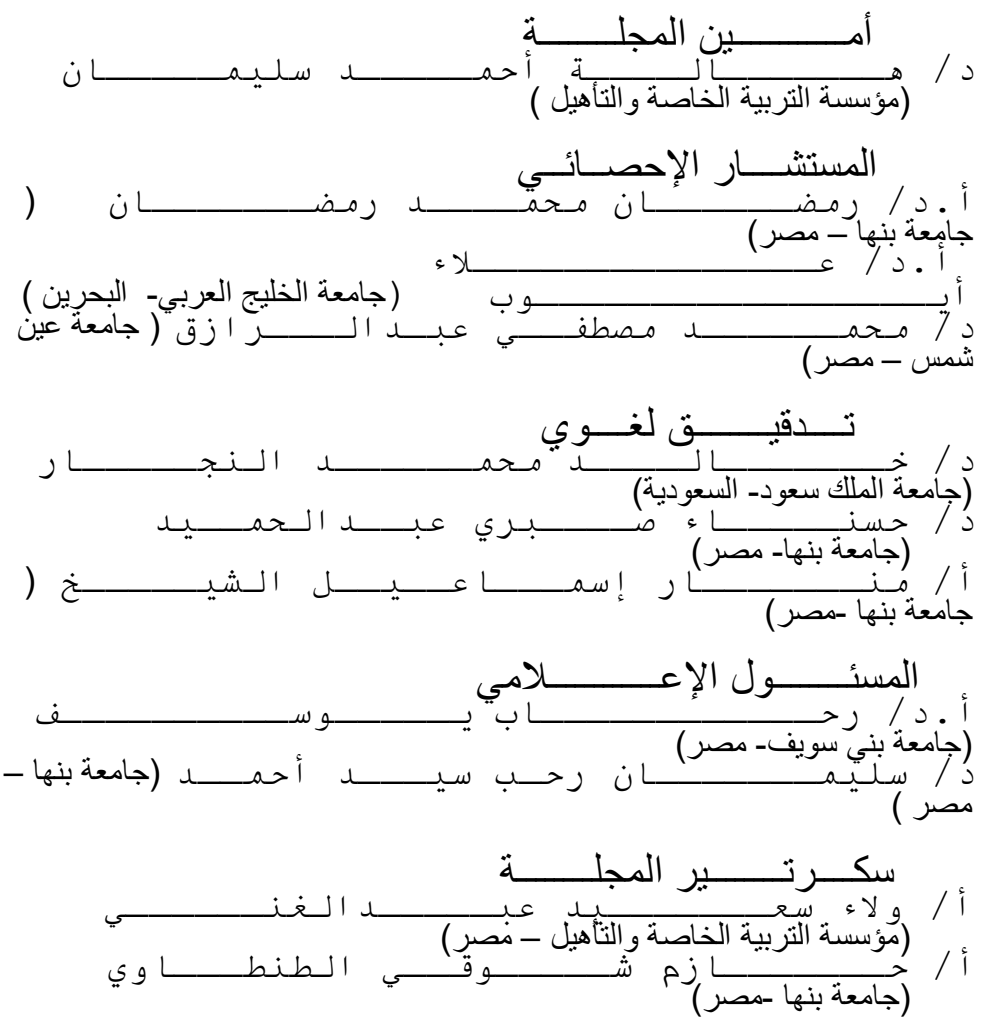


\section{اللجنانة الإشرافية كلية التربية - جامعاة بنها}

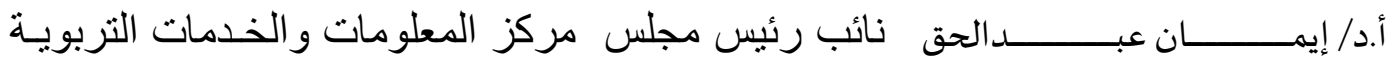
و النفسية والبيئية، ووكيل كلية التربية لثؤون البيئة وخدمة

المجتمع.

أ.د/ صــلاح الــدين محمــد توفيـق م مـدير مركـز المعلومـات والخــدمات التربويــة والنفسـية

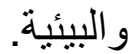

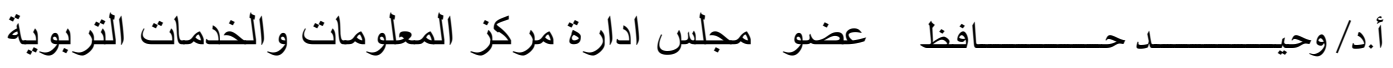
و النفسية و البيئية.

عضو مجلس إدارة مركز المعلومـات والخـدمات التربويـة

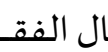

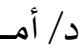
و النفسية و البيئية. 


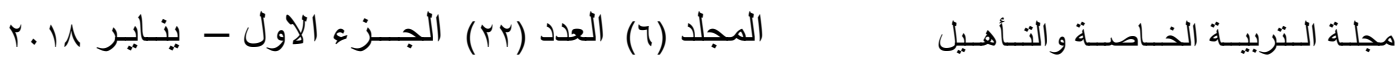

\section{الهيئــة التنسيقيــة}

\begin{tabular}{|c|c|c|}
\hline الـدولـة & الجـــامعــة & الاســـم \\
\hline 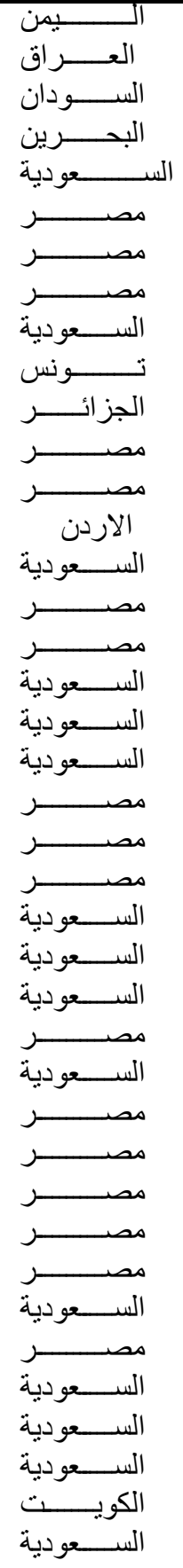 & 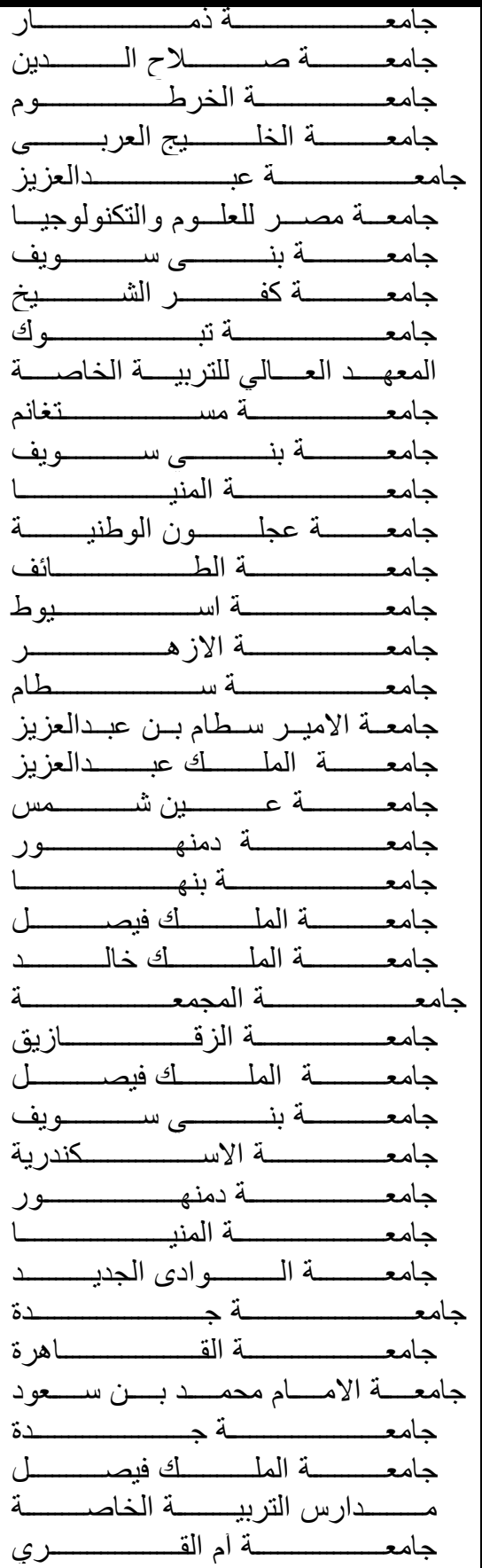 & 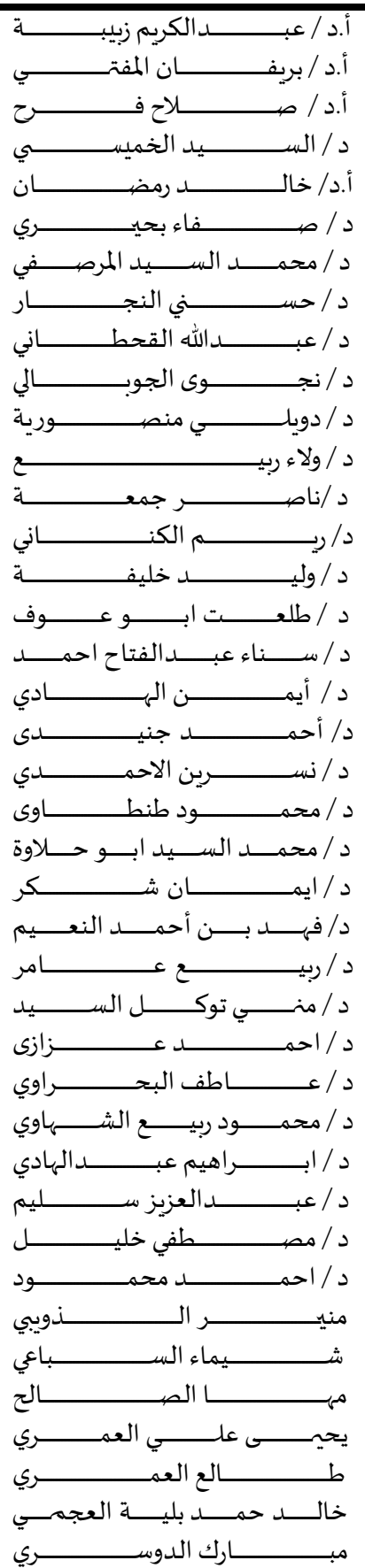 \\
\hline
\end{tabular}

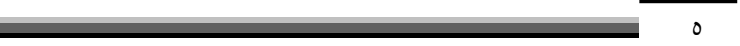




\section{التعريف بمجلة التربية الخاصية والتأهيل}

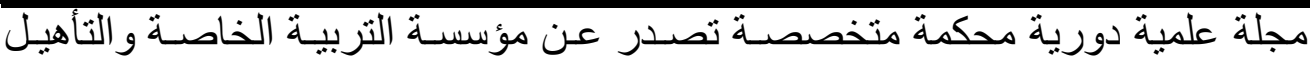
Special "Education and Rehabilitation Organization(SERO)

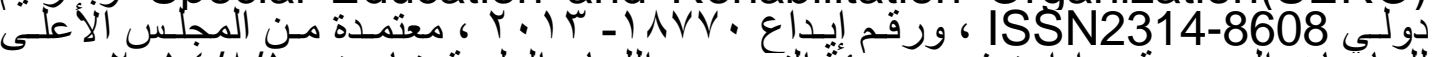

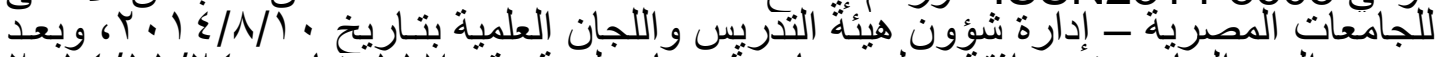

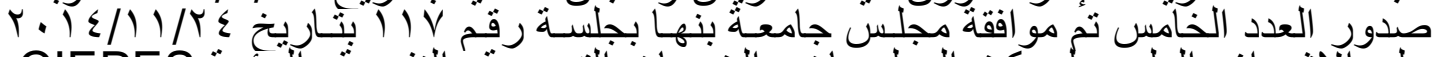

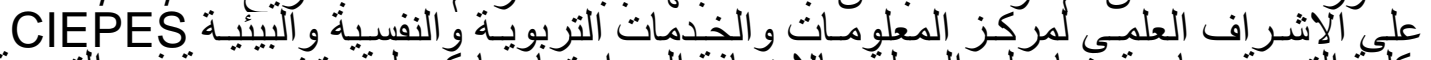

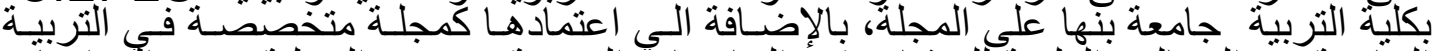

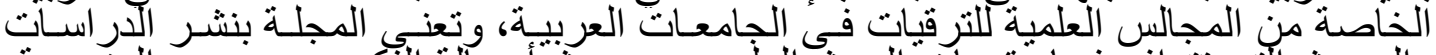

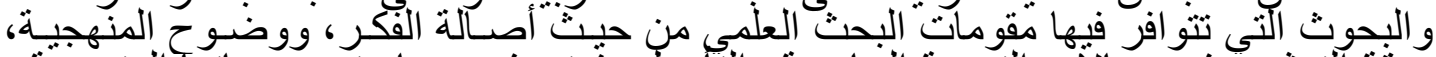

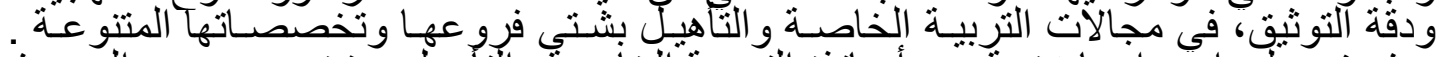

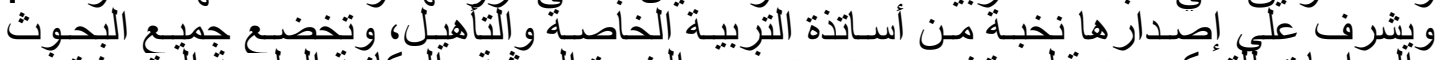

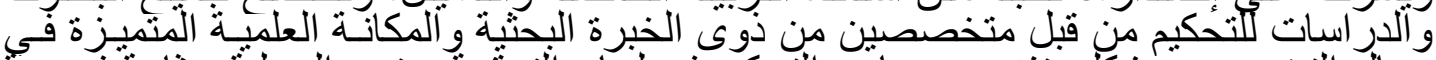

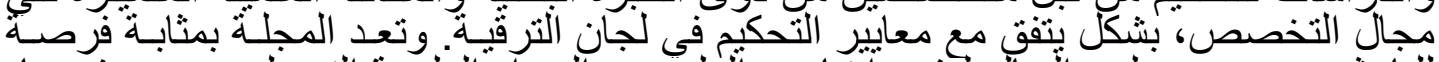

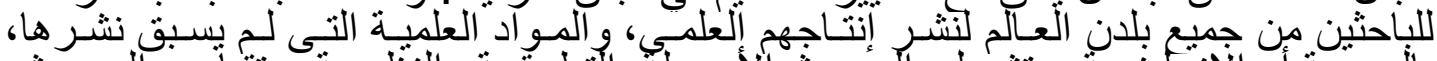

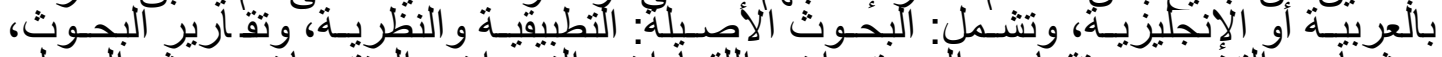

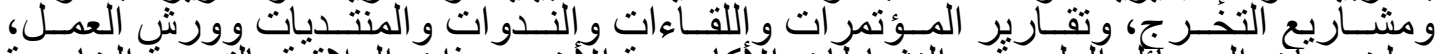

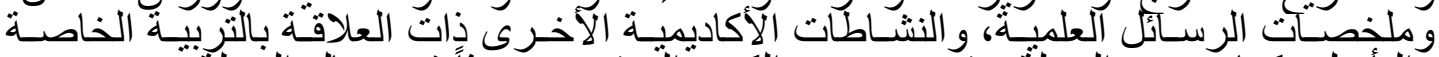

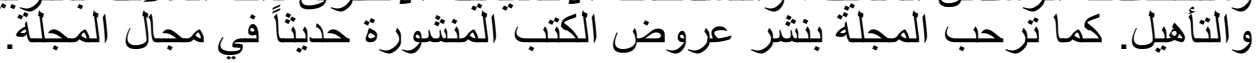

\section{رؤيسـانة المجلـــة}

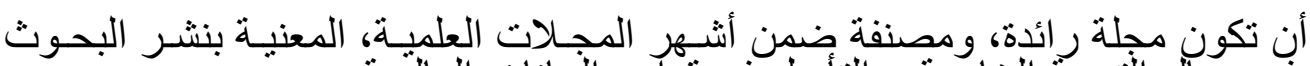

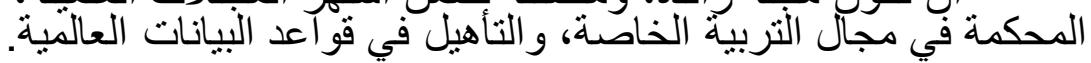

\section{رسبالـة المجلـة فئة}

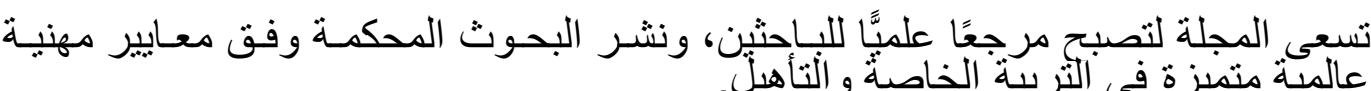

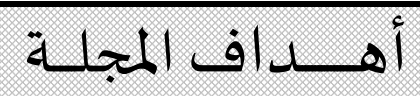

إيجاد و عاء أكاديمي متخصص في في مجال التربية الخاصة و التخأهيل.

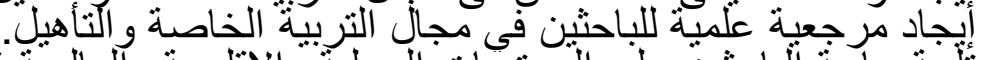

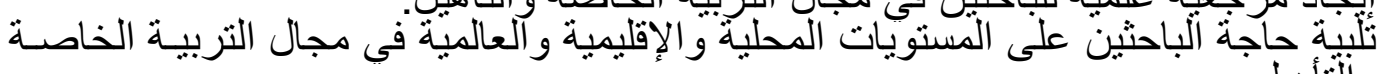

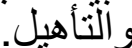

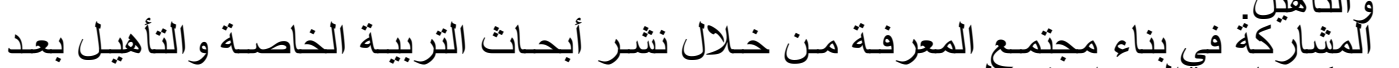

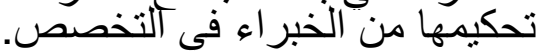




\section{اللجنـة العلميـة(")}

ا. أد/ طريف شوقي فرج ( جامعةً بنى سويف- مصر )

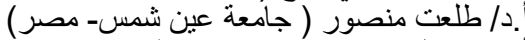

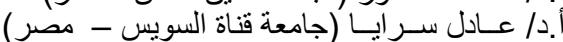

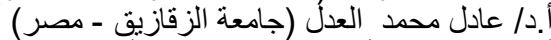
ا. أد/ عبد الرقيب أحمد البحيري(جامعة أسيوط - مصر ) أ.د/ عبداله محمد أحمد الجغيمان (جامعة الملك فيصل- السعودية

ا. ا. د/ عبدالرحمن سيد سليمان ( جامعة عين شمس - مصر )

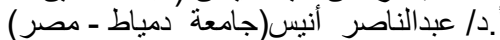
أ.د أد/ عبدالو هاب محمد كامل (جامعة طنطا- مصر) ) ا. أ.د/ علي حسين بداري (جامعة المنيا- مصر)

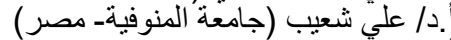
أ.د/ علي مهذى كاظم ( جامعة السلطان قابوس - سلطنة عمان)

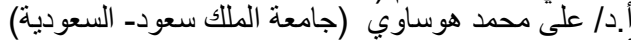

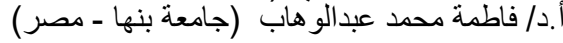

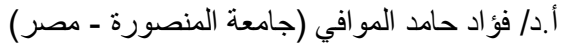

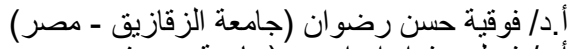

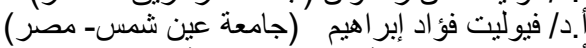

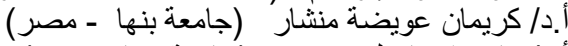

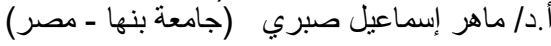

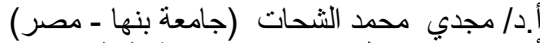

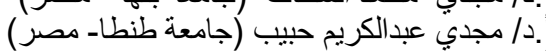

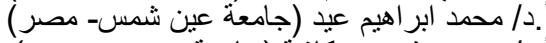

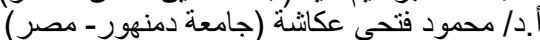

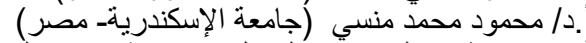
أ.د/ محفوظ عبدالستار آبو الفضل (جامعة جنوبة الو لوادى -

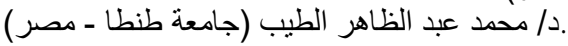

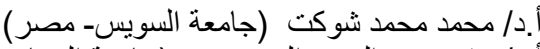

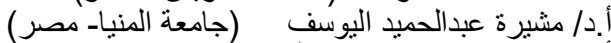

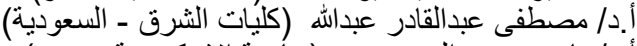

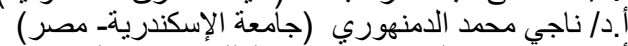

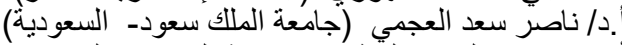
أ.د/ نجاة عبدالعزيز المطوع (جامعة الكويت ـ الكويت) أ.د/ وفاء محمد كمال عبدالخالق (جامعة القاهرة - مصريت ) . .د/ هشام عبدالرحمن الخولى ( جامعة بنها - مصر )

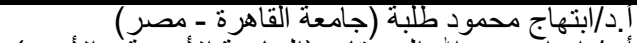
أ.د/ إبراهيم عبداله الزريقات (الجامعة الأردنية - الأردن)

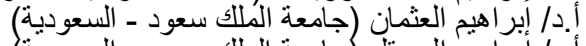
أ.د/ أبر اهيخ المعيقل (جامعة الملكي سعود - السعوديةية) أ. أدد/ أحمد عثمان طنطاوى (جامعة بني سويف - مصر ) )

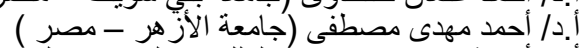

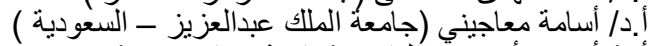

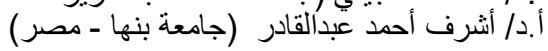

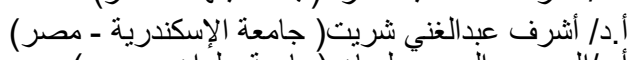

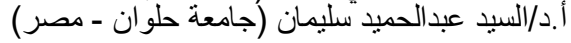

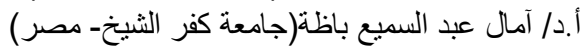

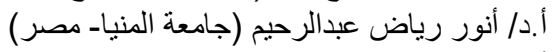

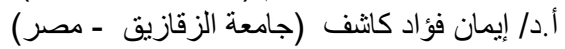

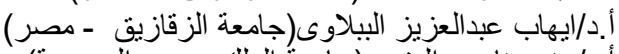

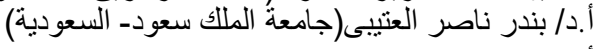

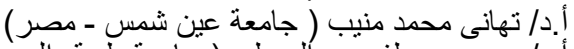

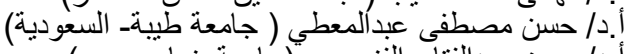

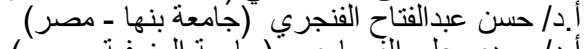

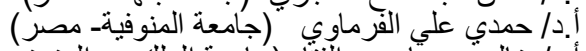

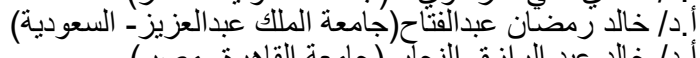

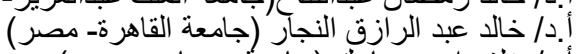

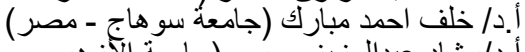

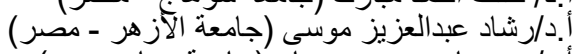

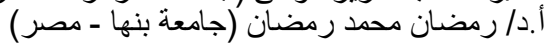
أ.د/ زيد محمد البنال(جامعة الملك سعود (جدان السعودية) أ.د/ زيدان السرطاوى(جامعة الملاك سعودـ- السعودية)

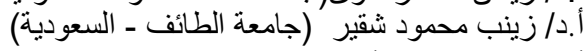
أ.د. سامية لطفى الأنصاري ( جامعة الإسكندرية- مصري)

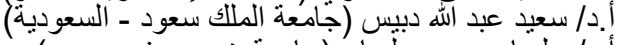

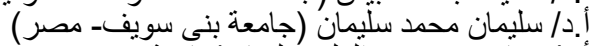

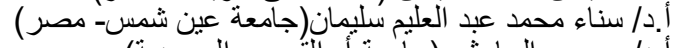

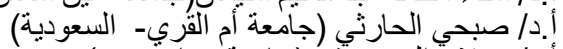

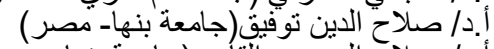

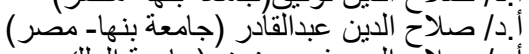

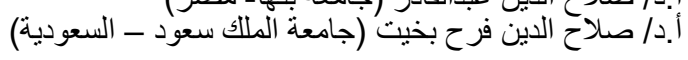




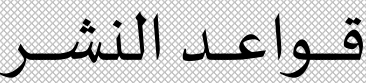

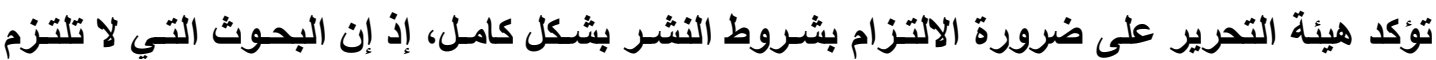

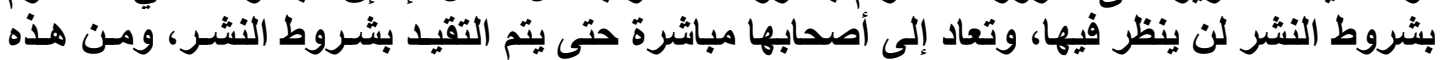
7- ـ تدرج الجداول في النص وترقم ترقيماً متسلسلاً وتكتب عناوينهـا.

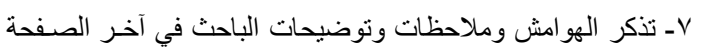

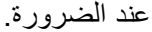

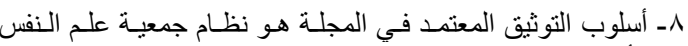
الأمريكية، الإصدار السادس:

(American Psychological Association- APA-6th ED)

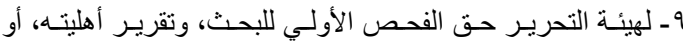
رفضه للنشر.

• 1 ـ في حالة قبول البحث للنشر تئول كل حقوق النشـر للمجلـة، و لا

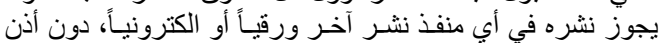
كتابي من رئيس هيئة التحرير.

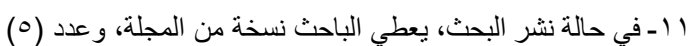
متسلّسلات من الدر اسة.

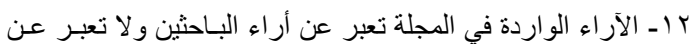

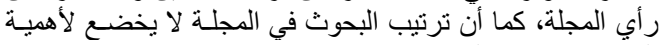
البحث و لا مكانة الباحث. آن تئ.

با ا ـ يتم تقديم البحوث الكترونياً على برنامج Word من خلال البريد

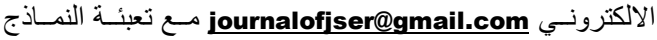

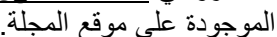

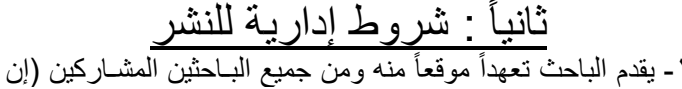

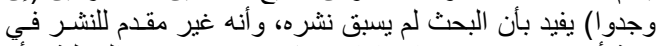

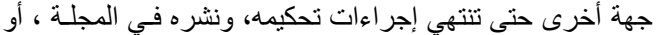

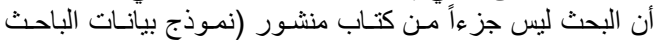

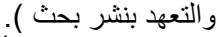
Y- لا يجوز نشر البحث أو أجز اء منه في مكان آخر، بعد إقرار نشره

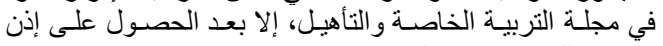
كتابي بذلك من رئيس التحرير.

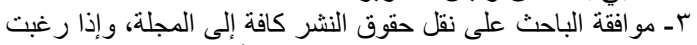

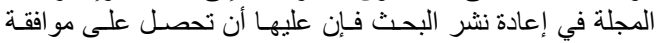

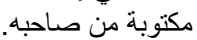

ولمزيد من المعلومات : برجى الدخول على الموقع الالكتروني التالي: www.sero-eg.com
الشروط ما يلي: الثيز لئن

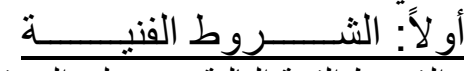

$$
\begin{aligned}
& \text { بجب نو افر الثروط الفنية التالية عند تسليم البحث }
\end{aligned}
$$

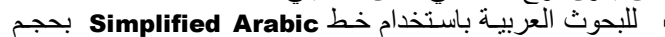

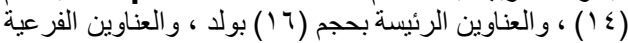

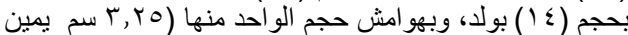

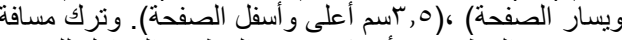

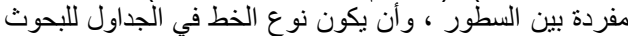

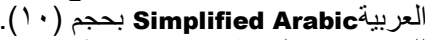

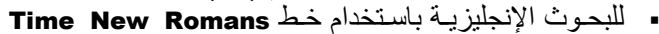

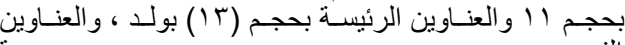

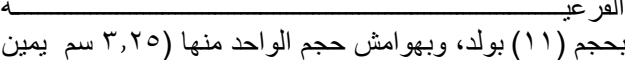

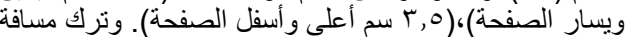

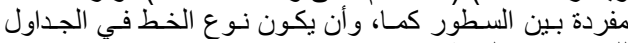

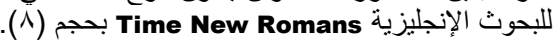

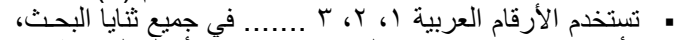
وأن يكون ترقيم صفحات البحث في منتصف أسفل الصفحة.

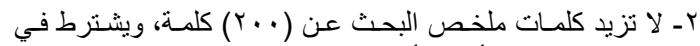

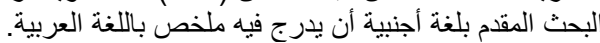

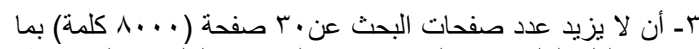

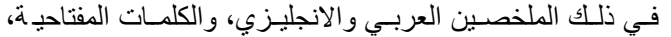

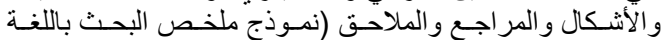
العربية و اللغة الانجليزية).

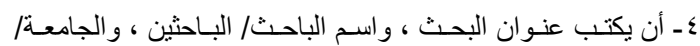

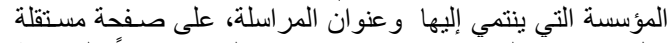

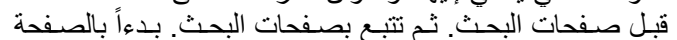
الأولى حيث يكتب عنو ان البحث فقط متبو عاً بكامل البحث

هـ أن يتكون البحث من العناصر التالية:

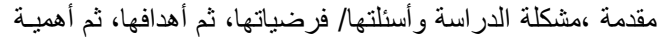

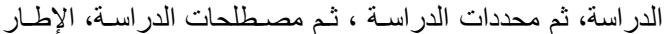

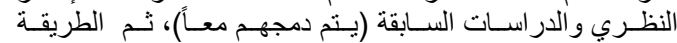

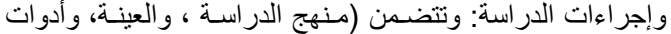

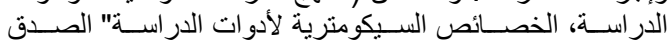

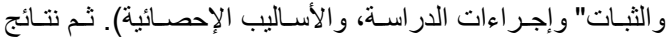

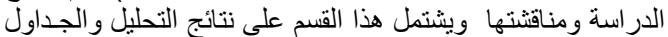

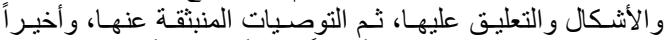

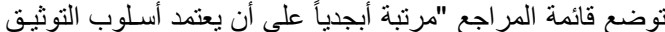

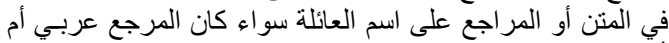
و المناحق إن وجدت 


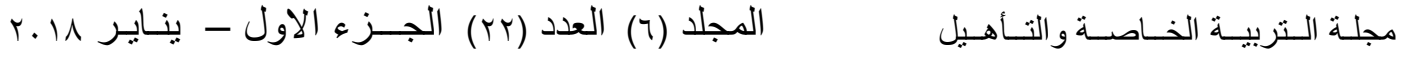

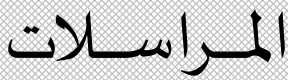

ترسل البحوث وجميع المراسلات المتعلقة بالمجلة إلى البريد الالكتروني للمجلة:

\section{journalofiser@gmail.com}

• أو إلي رئيس هيئة تحرير مجلة التربية الخاصة و التأهيل:

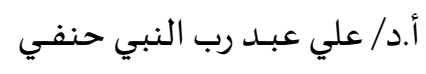

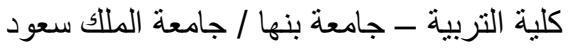

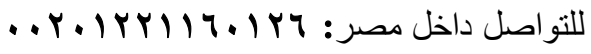

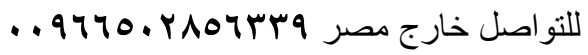

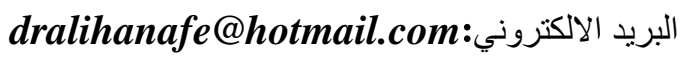

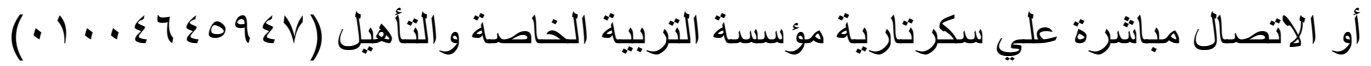

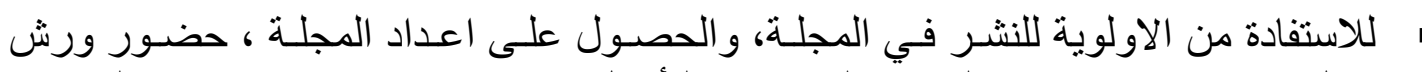

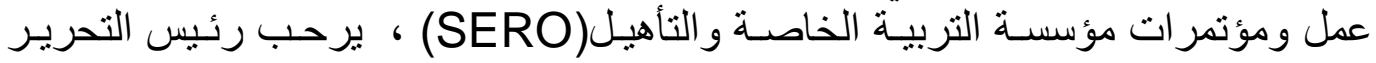

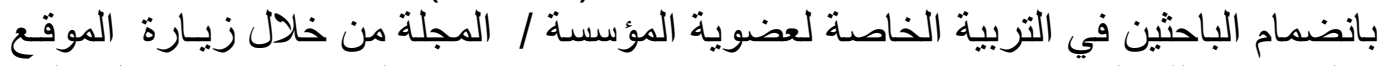

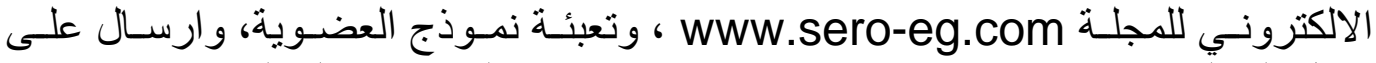

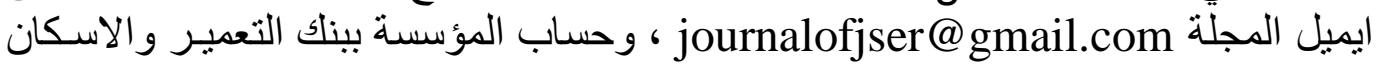
فرع بنها (0180000012150). 


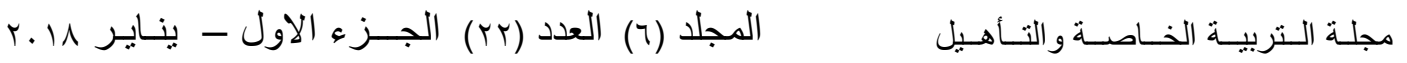

$$
\text { jar. }
$$

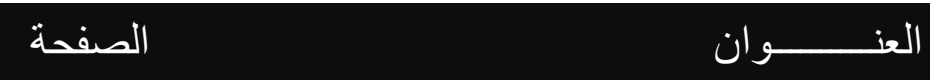

5

$$
\text { افتتاحية العدد (رئيس هيئة تحرير المجلة)... }
$$

$5-J$

$$
\text { أ.د/ علي عبد رب النبي حنفي }
$$

$$
\text { تقديم العدد }
$$

\section{أ.د/ ايمـان كـاشـف}

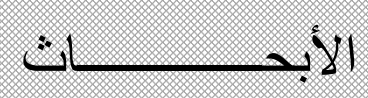

طبيعة الخدمات المساندة والتسهيلات المقدمة للطالبـات ذوات الإعاقـة بجامعـة

$r 7-1$

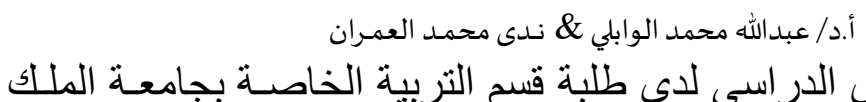

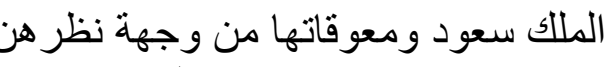

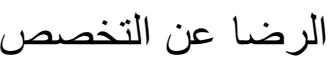

$7 r-r V$

د/ميحمان بن ناصر الرشيدي

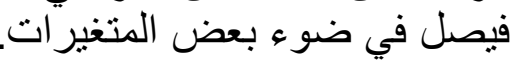

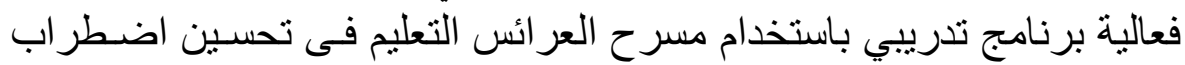
قصور الانتباه المصحوب بالنشاط الحركي الزائد لـدى التلامبذ ذوى الإعاقة

$1.9-74$ د/ مكي محمد مغربي

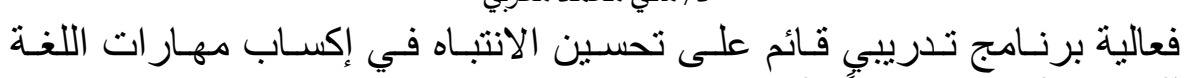

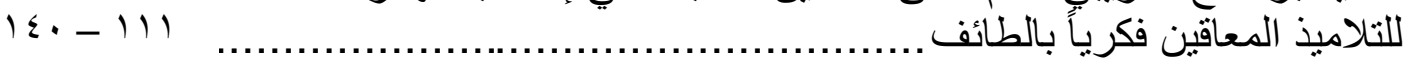

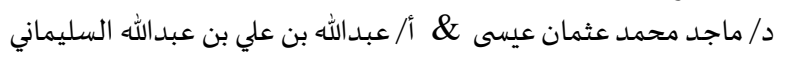

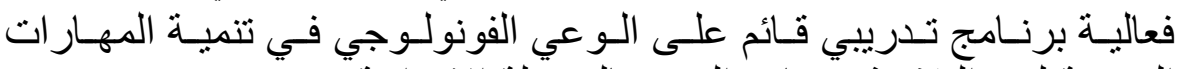

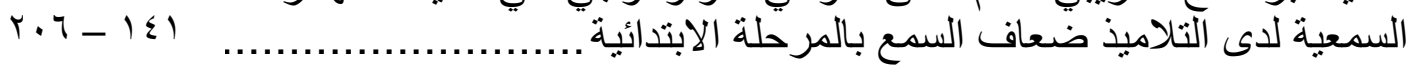

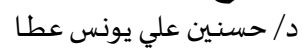

$r \leqslant 1-Y \cdot V$

و اقع العمل الجماعي بين معلمات التعليم العام و التربية الفكرية في دعبن دعم تعليم أ / أحلام بنت محمد الأشجعي 


\section{افتتـاحيـة العـدد}

$$
\text { أ. أ.د / عـلى عبــد رب النـبـي }
$$

حن

يسـعد مجلـة التربيـة الخاصـة و التأهيـل (JSER) أن تقدم للبـاحثين في مجـال التربيـة

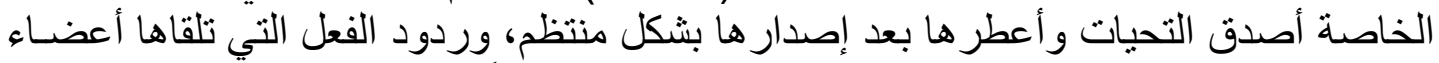

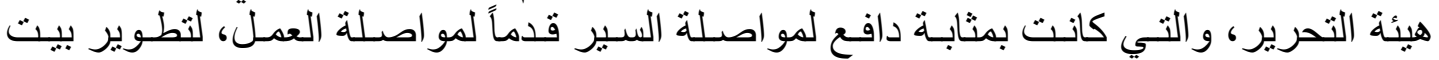

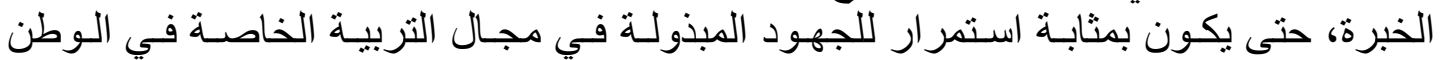

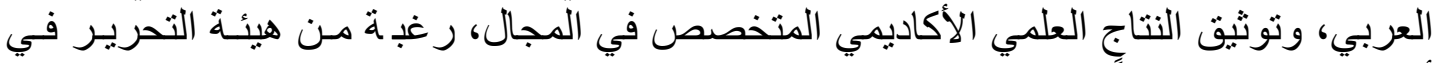

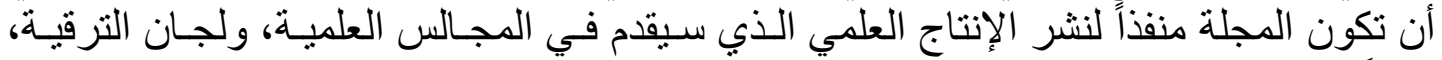

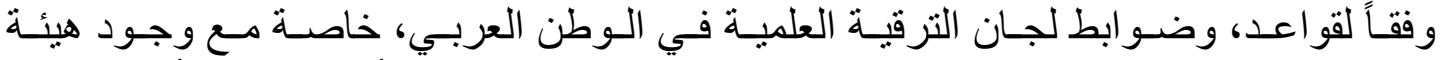

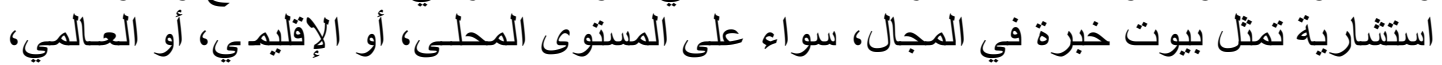

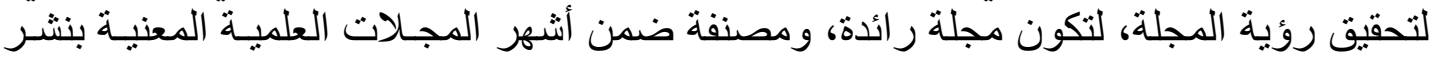
البحوث المحكمة في مجال التربية الخاصة و التأهيل في قو اعد البيانات العالمية.

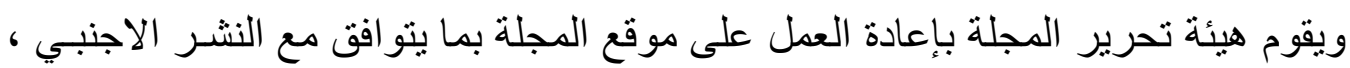

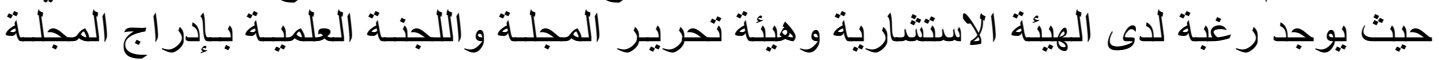

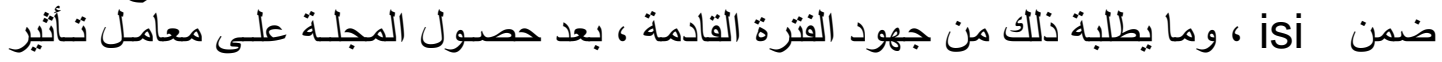
عربي عالي كمجلة متخصصة في الوطن العربي.

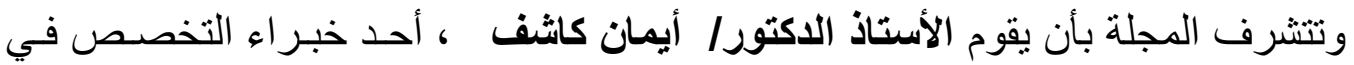

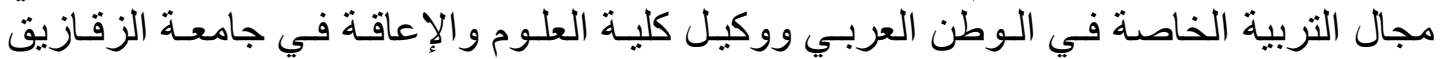
بتقديم العدد الثاني و العشرون.

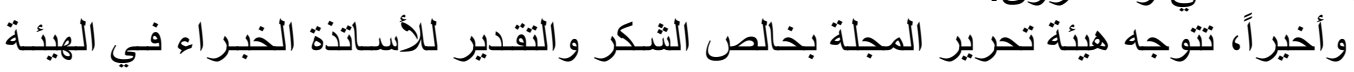

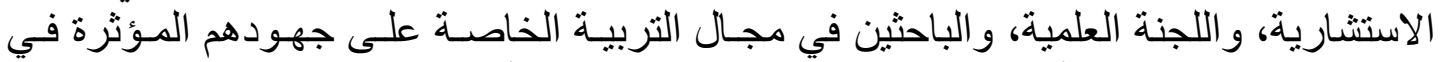

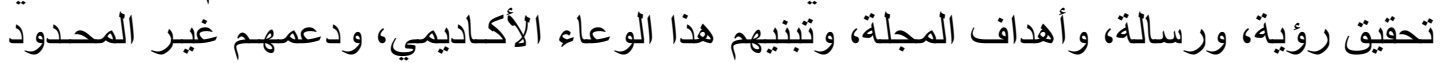
الذي يقدم للارتقاء بالمجلة، لتصبو إلى مجار اة المجلات العالمية. تحياتي وتقديري،6، 


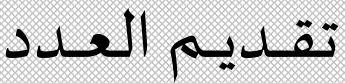

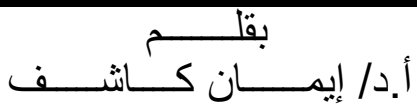

يشهـ العالم حركة سريعة من التقدم و التطـور في شـتى ميـادين العلـم وخصوصنًا مجـال

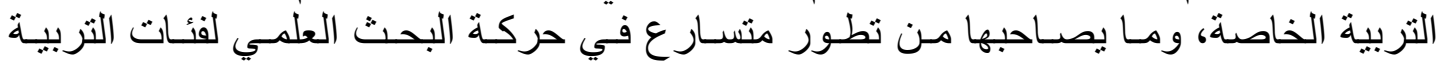

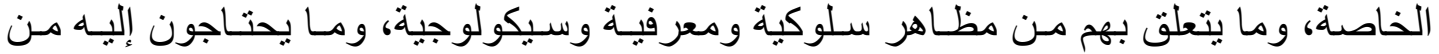

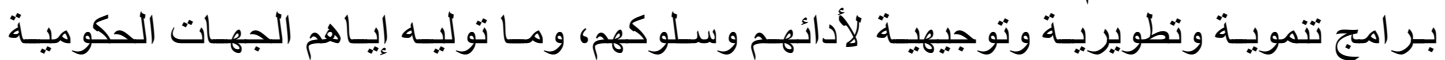

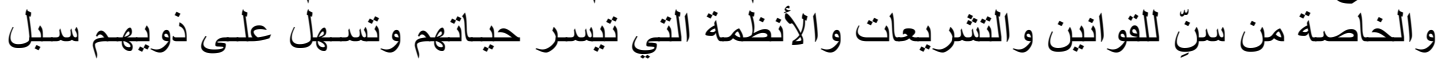

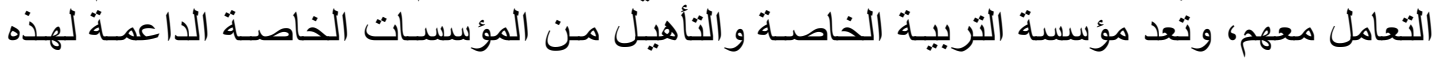

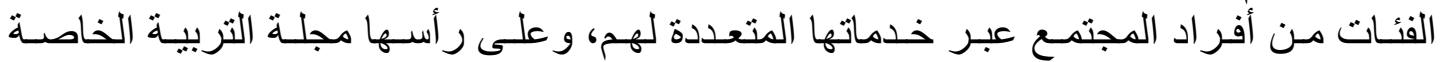

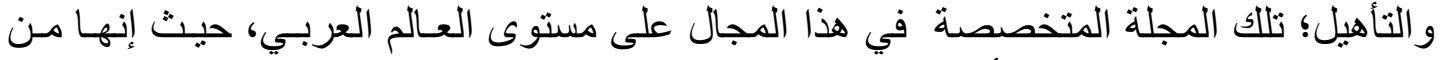

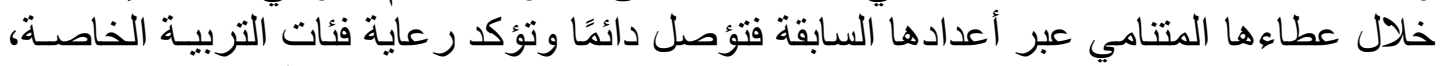

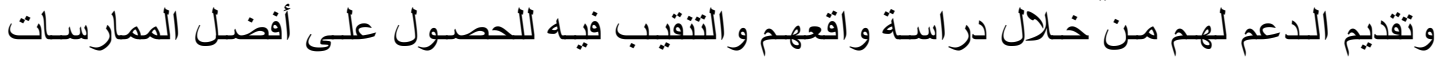

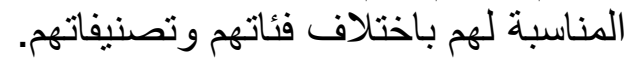

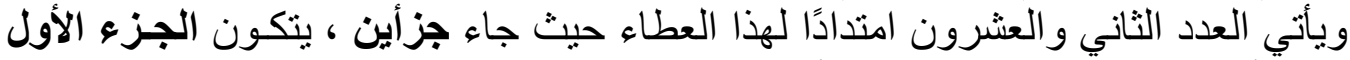

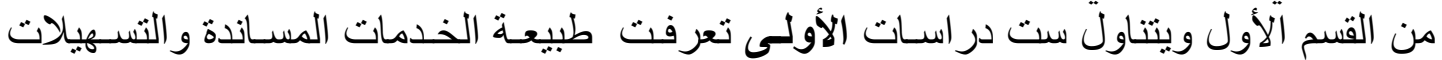

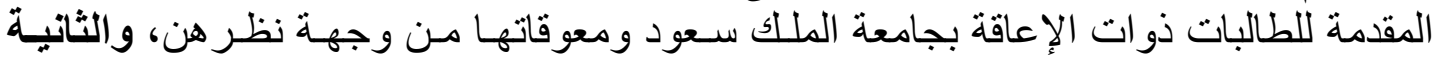

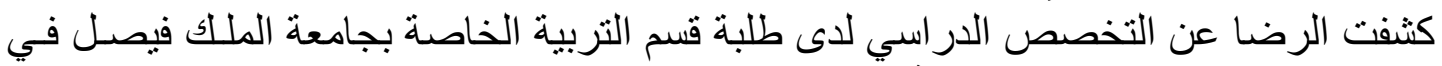

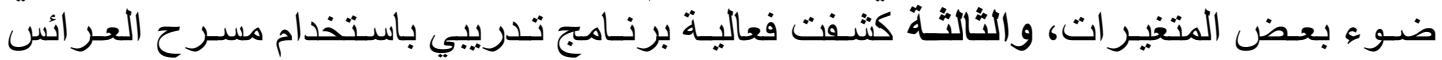

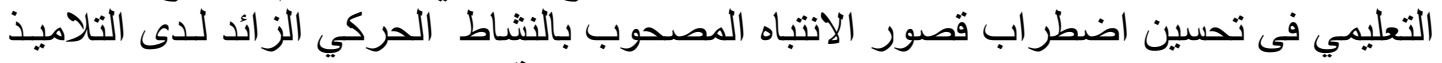

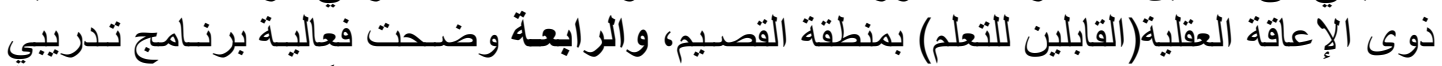

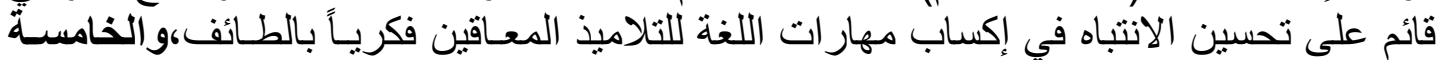

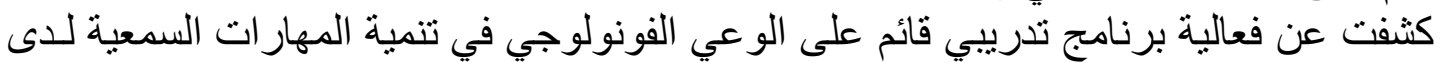

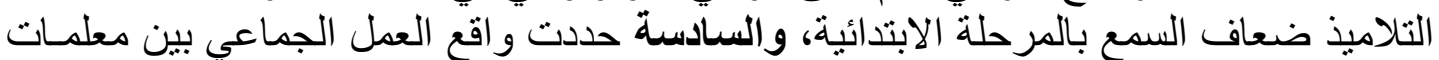
التعليم العام و التربية الفكرية في دعم تعليم التلميذات ذوات التئة الإعاقة الفية الفكرية.

وتناول الجزء الثاني من العدد خمس در اسات، الأولي كثفت عن و اقع ومشكاهلات تقبيم

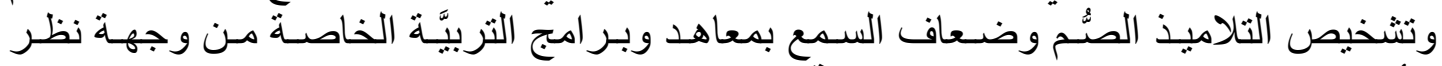

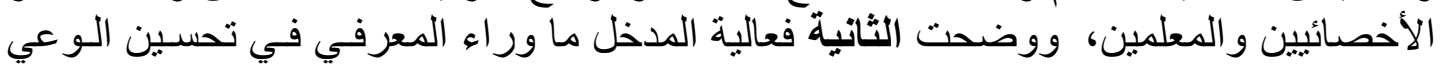

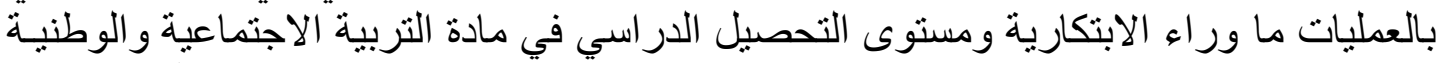

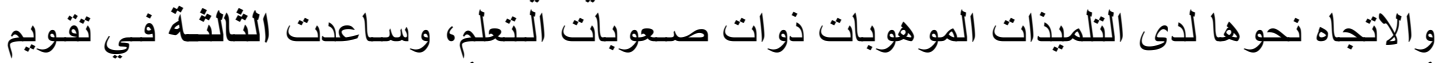

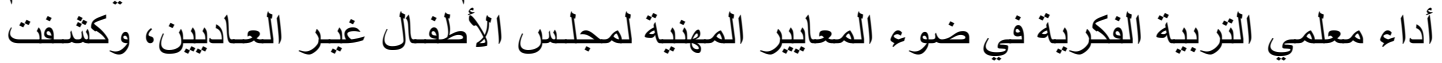

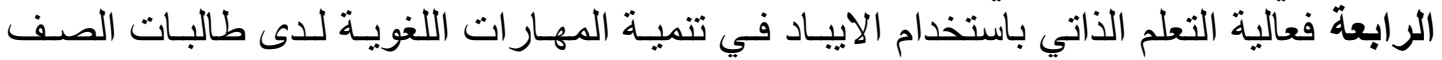

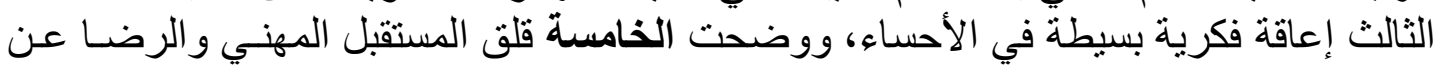




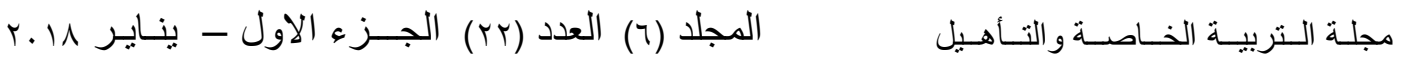

التخصص الدر اسي كمنبئات بالتحصيل الأكاديمي لاى طـلاب شـعبة التربيـة الخاصـة بجامعـة قناة السويس.

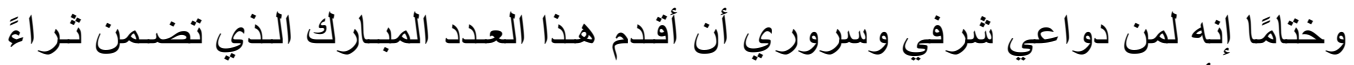

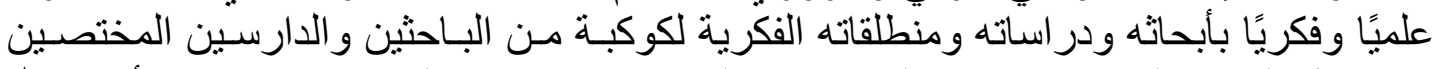

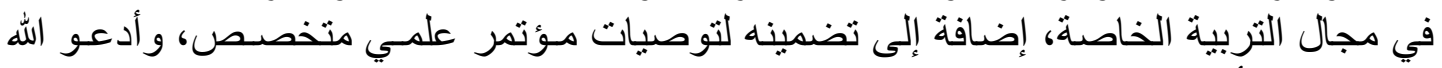

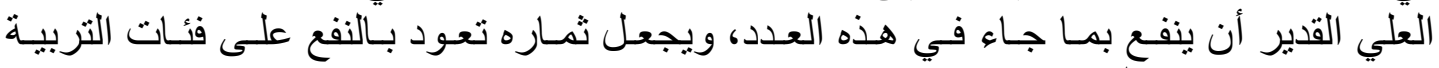
الخاصة وذويهم، و الله من وراء القصد وهو الهادي إلى سواء السبيل،،كي،

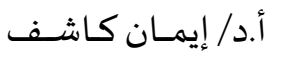

أحد خبراء التخصص في مجال التربية الخاصة في الوطن آنمان

$$
\begin{aligned}
& \text { العربي التجال }
\end{aligned}
$$

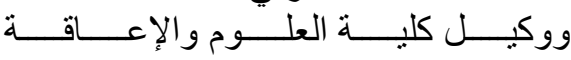

$$
\begin{aligned}
& \text { في جامعـــــة الزقة كــازيق الإع }
\end{aligned}
$$

